\title{
QTc prolongation among hydroxychloroquine sulfate-treated COVID-19 patients: An observational study
}

\author{
Bashar Fteiha ${ }^{1}$, Hani Karameh ${ }^{1}$, Ramzi Kurd ${ }^{1}$, Batsheva Ziff-Werman ${ }^{1}$, Itamar Feldman ${ }^{1}$, \\ Alon Bnaya ${ }^{1}$, Sharon Einav ${ }^{1}$, Amir Orlev ${ }^{1}$, and Eli Ben-Chetrit ${ }^{1}$ \\ ${ }^{1}$ Shaare Zedek Medical Center
}

June 17,2020

\begin{abstract}
Background: The liberal administration of hydroxychloroquine-sulphate (HCQ) to COVID-19 patients has raised concern regarding the risk of QTc prolongation and cardiac arrhythmias, particularly when prescribed with azithromycin. We evaluated the incidence of QTc prolongation among moderately and severely ill COVID-19 patients treated with HCQ and of the existence of concomitant alternative causes. Methods: All COVID-19 patients treated with HCQ (between Mar 1 and Apr 14, 2020) in a tertiary medical center were included. Clinical characteristics and relevant risk factors were collected from the electronic medical records. Individual patient QTc intervals were determined before and after treatment with HCQ. The primary outcome measure sought was a composite endpoint comprised of either an increase [?] 60 milliseconds (ms) in the QTc interval compared with pretreatment QTc, and/or a maximal QTc interval >500 ms. Results: Ninety patients were included. Median age was 65 years (IQR 55-75) and 57 (63\%) were male. Thirty-nine patients (43\%) were severely or critically ill. Hypertension and obesity were common ( $\mathrm{n}=23$ each, $26 \%$ ). QTc prolongation evolved in fourteen patients (16\%). Age > 65 years, congestive heart failure, severity of disease, C-reactive protein level, hypokalemia and furosemide treatment, were all associated with QTc prolongation. Adjusted analysis showed that QTc prolongation was five times more likely with hypokalemia [OR 5, (95\% CI, 1.3-20)], and three times more likely with furosemide treatment [OR 3 (95\% CI, 1.01-13.7)]. Conclusion: In patients treated with HCQ, QTc prolongation was associated with the presence of traditional risk factors such as hypokalemia and furosemide treatment.
\end{abstract}

\section{Hosted file}

Manuscript final.doc available at https://authorea.com/users/334336/articles/460335qtc-prolongation-among-hydroxychloroquine-sulfate-treated-covid-19-patients-anobservational-study

\section{Hosted file}

Table 1.doc available at https://authorea.com/users/334336/articles/460335-qtc-prolongationamong-hydroxychloroquine-sulfate-treated-covid-19-patients-an-observational-study

\section{Hosted file}

Table 2.doc available at https://authorea.com/users/334336/articles/460335-qtc-prolongationamong-hydroxychloroquine-sulfate-treated-covid-19-patients-an-observational-study

\section{Hosted file}

Figure 1.doc available at https://authorea.com/users/334336/articles/460335-qtc-prolongationamong-hydroxychloroquine-sulfate-treated-covid-19-patients-an-observational-study

\section{Hosted file}


Supplemental figure 2.doc available at https://authorea.com/users/334336/articles/460335qtc-prolongation-among-hydroxychloroquine-sulfate-treated-covid-19-patients-anobservational-study 